\title{
Fotoğraf Sanatsallığının İnşasında Işık ve Görsel Algı İlişkisi*
}

\author{
The Relationship between Light and Visual Perception in the Construction of Photography Artistic \\ İmran Uzun, Temel Eğitim Bölümü, Güzel Sanatlar Fakültesi, Kocaeli Üniversitesi
}

\begin{abstract}
Özet
Fotoğraf, etimolojik bir perspektiften bakılırsa ışıkla yazma, ıșıkla çizme sanatı olarak tanımlanır. Bu sanat (ya da uğraşı) varoluşunu ışığa borçludur. Bir nesnenin, duyusal olarak görülebilmesi için ya kendisinin bir ışık kaynağı olması gerekir, ya da üzerine düşen ışığı yansıtması gerekir. Ișı̆ı̆ın fotoğrafın sanatsallı̆̆ının inşa sürecindeki algısal biçimlenişini irdeleyen/tartışan bu çalışmada, görsel algının yapısını, insan gözünün görebildiği spektrumun fotoğraftaki biçimsel etkisini ve kavramsal algının somut ıșılkla kurduğu sembolik ilișkisini okumayı amaçlayan bir değerlendirme yapılmıștır. Amerikalı öncü sanat fotoğrafçısı Alfred Stieglitz'in dediği gibi 'Nerede ıșık varsa orada fotoğraf çekilebilir'. Ancak görüntüleri sadece işık ve makineler üretmez. Fotoğrafik ıșık ve görüntüleri yaratmak için, algının kaynaklarını, algısal inşanın ışığa yeniden biçim veren yönelimlerini, fenomenolojik ıșığın özünü iyice kavramak gerekir. Bu çalıșma, fotoğrafın sanatsallığının sanatçı tarafından yeniden yaratımında, ışığın görsel algı sürecindeki tasarlanma süreçlerine ilişkin betimleyici, tarihsel ve eleștirel bir okuma yapmayı amaçlamakta ve ıșığın yalnızca teknik olarak tartıșılmasını sorunlu bularak bilimsel tartışmalara algı odaklı yeni bir argüman sunmaktadır.
\end{abstract}

Anahtar Kelimeler: Fotoğraf, sanat, 1şık, görsel algı, fenomenoloji.

Akademik disipin(ler)/alan(lar): Fotoğraf.

\begin{abstract}
From an etymological perspective, photography is defined as the art of writing with light and drawing with light. This art (or pursuit) owes its existence to the light. In order for an object to be seen sensually, it must either have a light source itself or reflect the light falling on it. This study which examines and discusses the perceptual formation of light in the construction process of the art of photography, is an evaluation that is aimed at reading the structure of visual perception, the formal effect of the spectrum visible to the human eye on photography, and the symbolic relationship of conceptual perception with concrete light. As pioneering American art photographer Alfred Stieglitz said, 'You can take pictures wherever there is light'. But the images are not just produced by light and machines. In order to create photographic light and images, it is necessary to grasp the sources of perception, the orientations of perceptual construction that reshapes the light, and the essence of phenomenological light. This study aims to make a descriptive, historical and critical reading of the design processes of light in the process of visual perception in the artist's recreation of the art of photography and offers a new perceptionoriented argument to scientific debates.
\end{abstract}

Keywords: Photography, art, light, visual perception, phenomenology.

Academical disciplines/fields: Photography.

* Bu makale, yazarın 2014 yılında Atatürk Üniversitesi 'Fotoğraf Anasanat Dalı' programı çerçevesinde savunduğu 'Işı̆̆ın fotoğraf sanatındaki öneminin incelenmesi' ismini taşıyan yüksek lisans tezinden ve 2019 yılında Atatürk Üniversitesi 'Resim Anasanat Dalı' programı çerçevesinde savunduğu 'Fotoğraf sanatında soyutlama' doktora tezinden üretilmiștir.

- $\quad$ Sorumlu Yazar: İmran Uzun, Temel Eğitim Bölümü, Güzel Sanatlar Fakültesi, Kocaeli Üniversitesi, Anıtpark.

- $\quad$ Adres: Temel Eğitim Bölümü, Güzel Sanatlar Fakültesi, Kocaeli Üniversitesi, Anıtpark Yerleşkesi, Cedit mahallesi İzmit/ Kocaeli.

- e-posta: imranuzun@bayburt.edu.tr

- ORCID: 0000-0002-3733-4915

- Cevrimiçi yayın tarihi: 05.07.2021

- doi: 10.17484 /yedi.823576 


\section{Giriş}

Habermas, insanlı̆̆ı ve dolaylı olarak tarihsel cepheyi kuran eylemlilik türlerini teknik ve ideoloji hattında değerlendirdiği, 'İdeoloji olarak Teknik ve Bilim' (1993) isimli yapıtında, rasyonel eylemin kendinden türeyen iletişimsel ve araçsal eylemlerin, tarihsel akışa yön ve biçim verdiğini savunmaktadır. Fotoğrafı bu anlamda, teknik ve iletişimin iç içe geçtiği mekanik aksamlı bir yaratıcı eylem olarak tanımlamak yerinde olacaktır. Ancak sanatın o zamana dek hiç olmadığı haliyle bir araçsal dolayımla icra edilmesi, fotoğrafın teknik yönlerine ithafen süregelen tartışmaların odağını oluşturmaktadır. Çünkü fotoğrafta kurulan kompozisyon, mekanik bir işleme süreci gibi görüldüğünde, fotoğrafın yalnızca kayıtlayıcı bir araç olduğu sonucuna varılabilir. Ancak olgular dünyası ile kurulan 'bakış' ve 'gözlem' ilişkisinin araçsal bir düzlemden geçerek anlamı katmanlara yaydığı yeniden yaratım izleği dikkate alındığında ise, bir sanatın karşı konulamaz cazibesi ile yüzleşilmektedir. Bu ikiliği tartışan Levoy’a (2011) göre, güzel sanatlar seçkisinde yalnızca küçük bir yer talep eden fotoğrafın, alegori ve süreğen yaşam olmak üzere iki türü vardır. Süreğen yaşamı kayıt altına almanın tarihsel birikim ve vakanüvislik değerleri olduğu yadsınamaz bir gerçeklik iken, semboller dili ile yeni anlamlara ufuk açmanın alegorik bir sanatsal uğraşı ile doğrudan ilintisi vardır. $\mathrm{Bu}$ nedenle fotoğraflayan ile fotoğraflanan arasındaki ilişkiler, fotoğrafa tanıklık edenler ve fotoğrafın kavramsal çerçevesinin de dâhil olduğu çok yönlü bir okuma pratiği ile anlaşılabilir.

Dolambaçlı ve kompleks gibi görünen bu sanatsal mukayesenin ardında, fotoğrafın oldukça basit ve saf bir duruşu vardır. Fotoğraf, nesnelerin ışığının ya da ışığın nesneler üstü varlı̆̆ının fotoğrafı olarak oldukça basit bir sunum ve yine oldukça karmaşı bir anlamsal birliktelik ya da çelişkileri kendinde saklı tutar. Bu nedenle fotoğrafın inşa ettiği sanatsal ışığın temsili, aynı zamanda fotoğrafı kompoze eden gözün bakışıyla ve görsel algilanışın sanatsal tezahürleriyle de ilişkilidir. Görsel algısını tamamlayamayan bir fotoğrafın fenomenolojik eğretiliği, teknik ve araçsal tamamlanışında bir takım çarpıklıklar ve algısal paralaks valansları çerçevesinde ışığın sanatsal yeniden üretimi bağlamından kopabilir.

Görsel algılamanın en önemli üç gereğinden (göz, yüzey, ışı) birisi olan ve plastik sanatlar alanını görünür kılan ışık öğesi, insanda sanat içtepisinin oluşmaya başladığı ilk andan itibaren süregelen dönemlerin, sosyo-kültürel etkileri ve düşünce yapısıyla birlikte biçimlenmiştir. Işık, göz için olduğu gibi görsel sanatlar için de her şeydir. Ancak görünür kılmanın ötesinde, plastik sanatlar alanında biçimlendirmeyi sonuca götüren bir etken olarak bazı tanımlamaların belirlenmesi gereği doğmaktadır.

Bu durumda, bilindik tarihsel sıralaması içerisinde biçimlendirici eleman olan ıșık öğesi için sıra dıșı bir değerlendirmeden söz edilebilir mi? Sosyo-kültürel yapı ve teknolojinin zincirleme etkilerinin günümüze ulaştırdığı ve bugünkü sonucunu oluşturduğu ışı öğesi için nasıl bir içerikten söz edebiliriz? Tüm bu sorular, görsel sanatlarda bir tasarım malzemesi ve tasarım alanında yaratıcı bir öğe olarak önem kazanan ışığın, ayrı bir kapsamda incelenmesi gereğini doğurur.

Kendiliğinden ışık yayan cisimlere ışılk kaynağı denir. Ișılk yaymayan cisimler karanlık cisimlerdir ki, bunlar bir ışık kaynağından gelen ışınları yansıttıkları için görülürler. Işık kaynağı olmayan cisimle, özelliklerine göre, kendi üzerlerine düșen ışığın bir bölümünü az ya da çok yansıtırlar. Çevremizdeki cisimleri görmemize ve renkleri ayırt etmemize yarayan ışık, doğada rastlanılan elektromanyetik dalga șekillerinden biridir. Tüm bu dalga şekilleri, iletici bir maddeye gereksinim duymadan boşluktan geçebilirler. Işık kaynakları doğal ışılk kaynakları ve yapay ışılk kaynakları olarak ikiye ayırabiliriz. Doğal ışık kaynakları güneș, ay (dolaylı olarak yine güneş!) ve yıldızlardır. Yapay ıșık kaynaklarını ise flaş, ev ampulü (tungsten ampul), floresan ampulü, cıva buharlı ampul, ateș ve mum olarak sıralayabiliriz (ikizler, 2003, s. 44-45).

Iş̧ı öğesini, biçimi belirleyen bir etken (araç) ve tasarım elemanı olarak diğer bir etken (değer) bakımından ele alırken sadece özdeksel yapısıyla değil, düşünce yapısının (felsefe-estetik) oluşturduğu etkilerin ilgileri içerisinde de değerlendirmek gerekir. Bu nedenle bugüne değin ışık öğesinin ilk yapay gölgeler oluşturmadan, içeriksizleştirme düşüncesine değin, günümüz tasarımına etkileri açısından ulaştığı sonuçların değerlendirilmesini içeren başlıklar baz alınmıştır (Karavit, 2006, s. 135).

Işılk öğesinin görsel sanatların başlangıcından bugüne kadar oynadığı rolleri bütün sanat dönemleri içerisinde her sanat yapıtı için tek tek, değerlendirmek, ıșığı sadece görünür kılan bir etken olarak ele aldığımızda bile oldukça geniş bir alana sahip olmasını gerektirmektedir.

Işığı üreten, taşıyan ya da yansıtan somutun tam anlamıyla 'ne' olduğu tartışması, felsefenin, bilimin ve sanatın kafa yorduğu müstakil bir uğraşıdır. Bu uğraşı en biçimsel haliyle somutun, mental/algısal ve hissel/duyusal ya da mekânsal ve nedensel bir tesir (Nedjadrasul, 2017, s. 1) olarak var olduğu gerçeğini sunmaktadır. Işığın somutluğu, bir tek hal ve biçimde, biricik olarak ya da yeknesak bir durumsallık sergilemez. Somut ışığın fenomonolojik tarafi, bir taraftan duyusallığı, diğer taraftan ise algısallığı ile ilintili 
bir işlev ortaya koymaktadır. Deneysel somut ışık, duyular yoluyla açıklanabilir ve bunun birçok bilişsel tezahürü vardır. Bu çalışmada, ıșığın duyusal alımlanışı ve algısal yeniden üretiminin derinliklerine inilmekte ve bu algısal işlemin fotoğrafın sanatsallık pratiği ile ilişkisine odaklanılmaktadır.

\subsection{Fotoğrafın Sanat Biçimselliği veya Araçsallaşan Tekniğin Sanatsal Biçimlenişi}

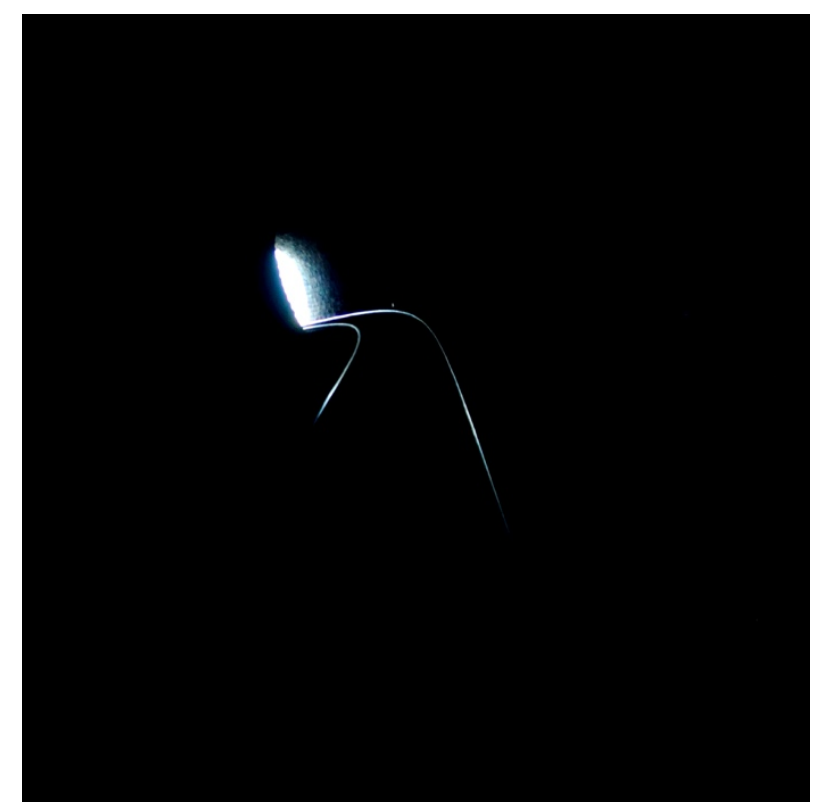

Şekil 1. Gün yüzü yaşam öncesinin tekil yolculuğu (Uzun, 2019).

Fotoğrafın anlatısal konumu yüzeysel bir kayıtlama ve zamanla ilişkisi bağlamına indirgenemez. Fotoğrafı mekanik bir kopyalama, tarih yazma ve anların kayıt altına alındığı bir dokümantasyon süreci olarak sınırlandırmak, fotoğrafın diliyle tarihi kıran, büken ve zamanın bağıl koşullarından kurtararak evrensel ebediliğe armağan eden yapıtlara karşı geniş çaplı bir haksızlık olarak addedilmelidir. Çünkü fotoğraf yapıtının dili, yalızca içeriğindeki objelerin taşıdığı düz anlamlar ile düşünülemez. Fotoğraf bu anlamda zamana ve mekana içkin gibi görünürken, art alanında zamansızlığın ve mekansızlığın hükmünü kurar. Bu durum Gün Yüzü Yaşam Öncesinin Tekil Yolculuğu adlı fotoğrafta görülebilir (Şekil 1):

Fotoğrafta işlenen soyut yaşam temasını kuvvetlendirmek amacıyla, yaşam ve ölüm arasındaki farkı temsil eden siyah ve beyaz renk kullanımları tercih edilmiştir. Nitekim bu renkler, fotoğrafın doğal ambiyansında ortam tarafından sunulan organik renklerdir. [...]Yaşamın bir evreler bütünü olduğu düşünüldügünde, başlangıç dönemlerini doğum anı ile sınırlandırmak yersizdir. Çünkü yaşam, doğum öncesinde başlayan ve doğum evresinde başka bir form kazanan koşullanılmış ilerleyiştir. Bir tünel ve ray gösteren kümesi ile doğum öncesi akışı temsil etmek, fotoğraftaki soyutlamanın sanatsal mantığını göstermektedir. Bu mantık, yaşamı ve yaşanmışlığı cansız nesneler ve onların kullanım biçimlerine bağlı olarak şekillenen çağrışımları hedef alan metaforik bir mantıktır. [...]Fotoğrafta gösterilmek istenen yaşam, karşıtı olan ölümle birlikte anlamlıdır ve yaşayan her şey ölümü düşündürmektedir. Ölümün sonlanışına karş̧lık, yaşamın başlangıcından kaynaklanan bir farkla meydan okunur. Yaşam toplum içerisinde aile, arkadaşlık ve cemiyet bağları ile çoğullaşsa da aslında oldukça tekil ve bireysel bir yolculuktur. Fotoğrafın soyut anlamı da bu tekilliği kurgulamak ve bir form diliyle anlatmak üzerinedir. (Uzun, 2019, s. 100-101)

Deleuze, araçsal eylemin sanatsal yönlerini tasvir ederken, sinema ve fotoğrafın da dahil olduğu mekanik kategorilerin varlığı anlamlandırmada geleneksel sanatlar kadar aşkın ve efektif olduğu görüşünü dile getirir. Deleuze'e göre (Colebrook, 2013, s. 78-80) fotoğraf ve sinema, mekân ve zamandan soyutladığı olgusal olanı, yersiz-yurtsuz ve zamansız bırakır. Sürekli değișmekte olan ve dünyasal zamana tabi olgusal konumlanışı, bir yerinden yakalamak ve bir daha hiç olamayacağı haliyle onu aslından koparmak, zamanın 
kendisiyle doğrudan bir hesaplaşmadır. Anın binlerce farklı fraksiyonunu yakalayıp kaydetmenin, sürüp gitmekte olan yaşanmışlığı diri ve canlı tutma gibi heyecanlı bir tarafı vardır. Bu yüzden Sontag'ın deyişiyle (1993), bir şeyi ve anı fotoğraflamak; ona sahip olmaktır. Çünkü fotoğraf sanatçısının sonsuz bakışlar anından bir anın kendisine ait olan parçasını çekip alması, ona sahip olması demektir. Sanatçı, kendi anını dilini konuşarak tarihe bir şeyler anlatır ve tarihi, sözlü anlatıların retoriğinden görsel dilin retoriğine aktarir.

Görsel dilin retoriğindeki fark ise, sözcüklerin abartılı dünyasında var olmayan oldukça bilişsel bir yorumlamadır. Çünkü geçmişi kuran bugünler konjonktürünün yorum perspektifi, görsel delillerin koruduğu anlamları tarihin hiçbir evresinde söz kadar esnetemez ya da çarpıtamaz. Fotoğraf dili, gerçek zamanın durağan görüntüsünden zamanlar arası pencereler açan ve yapıtı inceleyen kişiyi, sanatçının zamansız mekânının katmanlarına çağıran bir serüvene kapı aralar (Brash, 1983, s. 113-118). Fotoğrafın retoriği, durağan bir görüntünün statik olgusal düzenini, güneș ve yıldızları temsil eden dinamik semboller ve anlamlar yoluyla tarihin her evresinde kurulan canlı bir ilişkiler diline dönüștürür. Bu durum Yerkürenin Gökyüzü adlı fotoğrafta görülebilir (Şekil 2). Fotoğrafı incelemek, sanatçının anlattıklarının üzerine bir şeyler katarak, retorikteki canlılığı bir yerinden kavrayıp anlamın yaşamsal döngüsünü takip etmekle eşdeğerdir. Nitekim fotoğraf, her yönüyle canlılık içerir. Fotoğraf dilinin eklektik yapısı, şimdinin ebedi tekrarlarla kendini sürekli yeniden kurduğu etkileşim ve empati sarmalında büyümekte, genişlemekte ve yeni anlamlar üretmektedir.

Fotoğrafta kullanılan doğal gün ışığı, su üzerinde bir evren tasviri yaratmak amacıyla kullanılmıştır. Sudaki ışık kırılmaları yıldızları, güneş yansıması güneşin kendisini, kaya yüzey ise yerküreyi temsil etmektedir. Fotoğrafta evrensel bir görünü sağlamak amacıyla siyah, beyaz, sarı ve kahverengi tonları kullanılmıștır. Renkler arasındaki birlik, karanlık ve ışık ilişkisinden beslenmektedir. Fotoğrafta kurulan soyutluk, mimetik tarzda ışığın maddesel yüzeydeki çeşitli formları kullanılarak kompoze edilmiştir. Fotoğraftaki mimetik soyutlama, kavramsal bir düşünceden daha çok soyut benzetmeler içerdiği için ışığın zıtlıkları maddesel ve karanlıkla ilgili bir formasyonla ilintilendirilmiştir. (Uzun, 2019, s. 101-102)

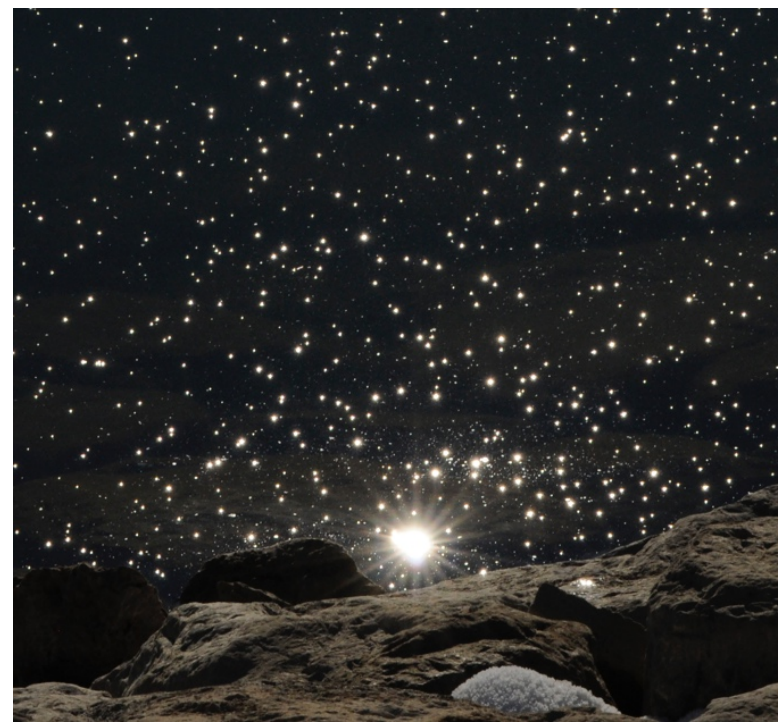

Şekil 2. Yerkürenin gökyüzü (Uzun, 2019).

Fotoğraf ve sinemanın sanatsal bir dili olup olmadığı tartışmalarına müdahil olan ve sanatsallık cephesinde saf tutan Arnheim, filmin sanat dilini konuştuğu 'Film as Art (Sanat Olarak Film)' kitabında, Filozof Cavell ise felsefi söylemlerinde fotoğrafın mekanik özelliklerinin yanıltıcı olmaması gerektiğini salık vermektedir. Fotoğraf, olguların temsil edildiği bir görüngüler evreni olarak arzu ve tatminin dolayladığı bir görsel temsil içermektedir. Natürel görünümün ardında dahi, salt bir kopya değil; insanın yaratıcı bilgisi, arzuları ve duygularıyla izole ettiği imgesel bir sanat pratiği vardır (Snyder \& Allen, 1975, s. 144-145). Nihayetinde natüralist yaklaşımda bile kurgusal mekaniğin domine ettiği bir üslubun varlığından söz edilebilir. Bu üslup, vizörle bakılan olgular dünyasının nasıl görüntüleneceği, ışık ve renk dengesinin anlamsal karşılığının nasıl 
hesaplanacağı, fotoğrafçının duruş yeri ve refleksleri ile doğallı̆̆ korumak adına nasıl bir katkıda bulunacağı üzerine farklı yaklaşımlar ve tekniklerle genişleyen bir konsepttir (Worringer, 2017, s. 37-39).

Fotoğraf sanatının dilini de belirleyen üslup, görüntüden ilhamla ve bizatihi görüntünün kendisi ile konuşmak isteyen fotoğrafçının, sanatın gerçekleştiği zaman ve birikim stoklarına karşı duruşunu da yeterince içermektedir. Bu nedenle bir fotoğraf, asla yalnızca bir fotoğraf değildir. Fotoğraf dili, kayıt eden göz ile tanık olan göz arasındaki gerçekçi ve yansımacı bir temastan ziyade, insana özgü semboller ve özdeşleyim hissine hitap eden sanatsal bir jargonu tümcelemektedir. Eco'nun (1989) 'Açılk Sanat Yapıtı' kategorisinde incelediği, yoruma açık bu temsil dili, görünen olgular düzeni ve espastan alınan evrensel bir duyum ya da algı değildir. Doğadan ve objelerden soyutlanan bu dil, sanatçının objelerin simgesel ve sembolik anlamlarını kompoze ederek konuștuğu görsel kodlarla yapılanır. Açık yapıta bakan gözlerin her biri farklı bir anlamın izini sürer. Bu dolayda, sanat yapıtı sanatçıya ait olmakla birlikte, taşıdığı anlamın çeşitliliği nedeniyle sanatçıya has olarak kabul edilemez. Anlamlar, herkesin üzerine bir şeyler söylediği kolektif bir sanat dilinin parçalarına yayılarak, insanlığın ortak değerlerine evrilir.

Eco'nun sanat yapıtının yorumsallığı üzerine sarf ettiği göstergebilimsel düşünceleri, Barthes'ın fotoğraf üzerine düşüncelerini kavramsallaştırdığı 'Camera Lucida' adlı eserinde paylaştığı Studium ve Punctum kavramlarıyla ortak çizgede okunabilir. Barthes'e göre (Barthes, 2008, s. 41-43), bir fotoğrafın seyredene sunduğu kompost anlamlılığı açımlamaya çabalamak ve semiyotik kodları çözümleyerek anlam üretmek işi, geniş kapsamlı bir girişim olarak Studium'dur. İlk bakışta, fotoğrafın semiyotik dünyasındaki bu geniş̧ arayışa yönelen gözler, bir dedektif misali anlamların izlerini takip eder. Düz anlam ve yan anlam çatışmasının ya da karmaşasının yarattığı gerilim, Studium ile birlikte ortaya çıkar. Punctum ise, sebebi açıklanmayacak şekilde, fotoğrafta baskın anlamdan kopuk ve tamamıyla öznel bir alımlamadır. Punctum, açıklanacak bir durum değildir ki, açıklamaya kalkışma hareketi ile birlikte Studium açığa çıkar. Örneğin, bir savaş fotoğrafındaki iki asker arasındaki öldürücü mücadelenin yer aldığı kompozisyonda, yerde duran bir taşa dikkat etmek ve fotoğrafı bu taşla anlamlandırmak Punctum'a işaret eder. Nitekim Barthes de iki çocuğun konumlandırıldığı tarihsel bir fotoğrafta, çocuğun çarpık dişlerinin kendisini çok etkilediğini ve bunu açıklayamadığını ifade etmektedir. Studium ile Punctum'un birlikteliğini içeren fotoğraflarda anlamın daha yoğun ve keskin olduğunu düşünen Barthes, bazı fotoğraflara anlam verilemeyecek kadar ayrıcalıklı bakılmasını Punctum'a bağlamaktadır (Barthes, 2008, s. 59). Eco ve Barthes'in semiyotik gözle baktıkları fotoğraf dilinde, birçok anlamı kesiştiren ve oldukça subjektif olan bir sonucu keşfetmeleri; fotoğrafın mekanik bir dille sınırlandırılamayacağına açıkça kanıt sunar. Fotoğrafın keşfedilmeyi bekleyen soyut ve sanatsal dili ise doğurgan bir yapıdadır.

Wicks'in (1989), 'Temsili Bir Sanat Olarak Fotoğraf' isimli makalesinde söyleme döktüğü yaklaşım, fotoğraf dilinin araçsallı̆̆ın yanı sıra sanatsallık taşıdığını anlatmaktadır. Çünkü temsil her şeyden önce bir baştan yaratmadır. Temsili, bir 'durum tanımı' olarak açıklayan Hall'in deyimiyle (Hall, 1999, s. 88), temsile konu olan gerçeklik, olguların basitçe yansıtıldığı ve verili göstergelerden oluşan bir kopya değildir. Temsil, gerçekliğin dolaylanarak ve durumlarının yeniden tanımlanarak kurulduğu yaratım eylemidir. Temsildeki dolaylama, soyutlamayla birlikte anlamlıdır. Gerçekliği, olduğu halden bambaşka ve zit bir halde de tanımlamaya imkân tanıyan temsilleştirme, fotoğraf dilinin yaratıcı gücünü yansıtmaktadır. Fotoğraftaki bir bardak nesnesi, yalnızca bir bardağın kopya edilmiş görünümden ibaret değildir. Bir bardağın fotoğrafı, bir bardak olarak yeniden tanımlanan bir bardağı içerir. Bu tanımlamadaki bardak ile fotoğraftan bağımsız bir obje olarak bardak arasında, fotoğrafın semiyotik kodları bağlamında ciddi farklılıklar vardır. Artık, fotoğrafçının ve fotoğrafa bakanların ortak dillerinde soyutlanan anlamlar vasıtasıyla bardağın olgusal gerçekliğinin aşıldığı kavramsal bir etkileşim söz konusudur.

Fotoğraf sonsuz sarmalda anlamı kuran karmaşık bir dille soyutlanmaktadır. Gösterilen şeyin bir bardak olması, gösterilmek istenen gerçekliğin bardaktan tamamen bağımsız bir anlamla kurulmasına engel değildir. Bir bardağın olgusal bedeninde anlatılmak istenen olgular üstü anlam, çoğu zaman bardağın kırılgan yapısını ve işlevlerini görünmez kılar. Bir fotoğraftaki bardak, kendisiyle hiçbir ilintisi bulunmayan oldukça insani bir mesaj verebilir. Bu durumda kestirilen mesajın, bardakla doğrudan ilişkisi olduğu ve aynı zamanda bardağın fotoğraf dışındaki gerçekliğiyle hiçbir ilişkisi olmadığı denklemi kurulabilir.

Temsil kuramını yapısalcı dil teorilerine paralel yönde kuran ve anlamı, dilin yapısal hareketliliği içerisinde üretilen sembolik bir temsil olarak gören Hall'e göre (Hall, 1997, s. 5), temsil edilenlerin dil ile doğrudan bağı vardır. Temsil, dil ve anlamın ortaklığında kurulmaktadır. Fotoğrafın temsil gücü, sanat dilini paylaşanların 'Kara Kutularındam (Camera Obscura)', karşılıklı görsel konuşmalarla inşa ettikleri başı ve sonu belirsiz bir tecrübedir. Başı ve sonu belli olmayan bu dil, deklanşöre basıldığı kayıt anından, sonsuz yorumlara ve genişlemeye uzanır. Fotoğrafın dili evrenseldir ve sözel olmayan bir sembolik düzen içerir. 
Görsel kültürün yükseldiği ve gözün egemenliğini tesis ettiği dijital çağda, fotoğraf dilini konuşan insanların sayısı giderek artmış ve Instagram ya da Youtube gibi görsel kompozisyonların üretildiği sosyal alanların kullanım örüntüleri büyümüştür. Artık yazıll ifadeler olmadan, yalnızca görsel kurgular ve sofistike sunumlar üzerinden anlaşan uluslar üstü bir cemiyet biçimi ortaya çıkmıștır. Bu dönemde fotoğrafın görsel kodlarının anlattı̆̆ı hikayelerin sanatsal yönünden uzaklaștığı varsayımı kuvvetlense dahi, soyutlayıcı pratiğin sanatla olan yakınlığı da yadsınamaz düzeydedir. Çünkü temsilin karakteri, kendisi dışında olana işaret eden bir anlamın üretimi ile ilgilenir. Fotoğrafta üretilen anlam ne olursa olsun, sanatın biçim dilini her zaman potansiyelinde taşır.

Fotoğraf dili, görsel retorik kadar ürettiği sanatsal söylemle de anlamlıdır. Çünkü olgusal evren, onu anlamlandıran gözün noksanlığında yalnızca 'şey'lerden oluşur. Tanımsız ve ne olduğu bilinmeyen bu 'şey'ler kolektifi, fotoğraf ya da diğer sanatların, bilimin ve felsefenin dili ile anlamlandırılır. Foucault bu anlamda yapıları 'şey'lerin dilsel tasvirleri olarak değerlendirir (Foucault, 1994, s. 188). Evrenin içerdiği 'şey'lerin anlamla yüklü olduğuna karşıt olarak gelișen bu görüş, dilsel yapılar ve söylem iliş̧isinin evreni anlamlı bir bütünlükle okuma firsatı verdiğini savunmaktadır. Fotoğrafta yer alan göstergeler, insani unsurlardan bağımsız düşünüldügünde yalnızca birer 'şey'dir. 'Şey'lere anlam kazandıran, fotoğrafın dili, fotoğrafçının katkısı ve fotoğrafa bakanların yorumlamalarıdır. Nitekim bir sanat olarak fotoğraf, yapısal anlam kurguları sayesinde birçok 'şey'in özündeki kavramsal anlama ulaşmaya aracılık etmektedir.

\subsection{Işığın Görsel Algılanışı: Somut Ișııtan Fenomenolojik Ișığa}

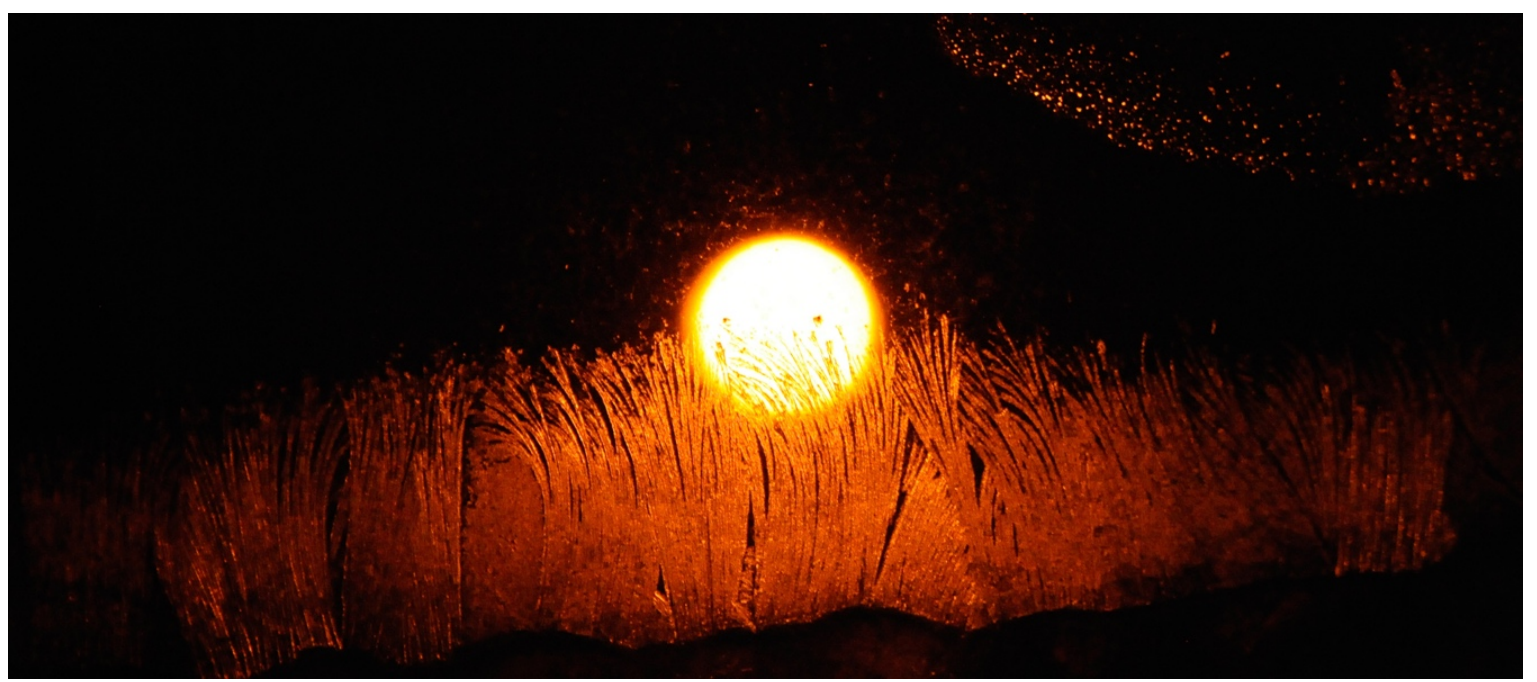

Şekil 3. Karanlıktaki kızıl aydınlık (Uzun, 2016).

Somut olan ışığın her şeyden önce görsel açıdan sembolik ve alımsal yönlü fenomenolojik bir değeri vardır. Bu durum Karanlıktaki Kızıl Aydınlık adlı fotoğrafta görülebilir (Şekil 3). Aydınlık, felsefi bir düşlem ya da eğretileme olarak gerek hümanist bir hareketi adlandırsın gerekse bir çağın ön adlığını üstlensin; daima kavramsal bir otonomi içerir. Çünkü aydınlık, ışığın kendisinde olan bir şey değil, onun etkisindeki bir şeydir. Aydınlık, gerçekliğin yazılışı yerine okunuşudur ve bu nedenle ışıkla yazılan değil, ışıkla okunan bir numendir. Karanlıktaki Kızıl Aydınlık adlığı, ışığın valanslarına bir atıf olmaktan daha çok, aydınlanma felsefesi içineki 'cehennem gerilimini' anıștırmadır. Nitekim aydınlanma, gelenekseli karanlıklaştırmak işi üzerine düşünülmüş tereddütlü, netameli, ateşli bir tansiyonla birlikte vardır. Üstelik bu varoluşu gereği, onun tarihsel konuşlaşı ile birlikte yorumlayıcıların tarihe karşı konuşlanışları da önem taşır. Nihayetinde oksidantalist aydınlanma fikri kimileri için, ıșığın asıl yeri olan Doğu'nun karanlıklaştırıldığı oryantalist bir kızıllık ve batım yeridir. Oysa tarihsel olarak bilindiği üzere; 'Ex Oriente Lux!' (Işık, Doğudan Yükselir!).

Sözel olarak simgeleştirilmiş ışık ise çoğu zaman doğadaki olgusal somutu farklı bir biçimde ve özgesel olarak yeniden kurmaktadır (Paivio \& Csapo, 1969, s. 280-282). Somut ışı̆̆ın doğadaki varlı̆̆ı, simgeler yoluyla bilince aktarılarak yeniden görselleştirilmektedir. Bu izlek, görsel-sembol-görselleştirme süreci şeklinde fenomenolojik olarak gerçekleşmektedir. Bu durum, Uçurumun Kenarındaki Işılk adlı fotoğrafta görülebilir (Şekil 4). Çünkü doğadaki ayrımlama, toplumsal ayrımlama ve sınıfsallaştırmadan daha keskin işleyen bir bölek deneyimidir. Doğa, nesnel olanı ve onun transendental/aşkın formlarını birbirlerinden ayırmak için natürel ve kavramsal tavrı melezleştirir. Bu melezlik içinde renkler içinde renk aranabilirken, aynı zamanda anlam içinde anlam ya da anlam dışında anlam irdelenebilir. Uçurumun Kenarındaki Işık, 
ayrışmaya dirayetli ya da birleșmeye arzulu bir eklektik kavramsallaştırma düşünündeki teredüdütleri barındırır. Somut ışığın olgusal varlığına duyusal/görsel tanıklık, bir sembol aracılığıyla onu algısal nesneye dönüştürmekte, zihinsel pratiğin dişlileri arasından yeni bir görsel somut yaratılmaktadır. Bu ışıksal somutlama, salt haliyle var olan bilinç dıșı somuttan farklı olarak oldukça sembolik ve insansıdır/algısaldır. Bunun da ötesinde ıșığın görsel somutluğunun algısal boyutunda, yani imgeleminde yaratılan yeni somut, bazı durumlarda özüne muhalefet uygulayarak muarız anlamlar üretebilmektedir. Somut sanatsal olarak, insan tarafından yaratıldığı için esnek yapılı, müdahaleye açık ve açılacak fenomenolojik bir 'şey’dir.

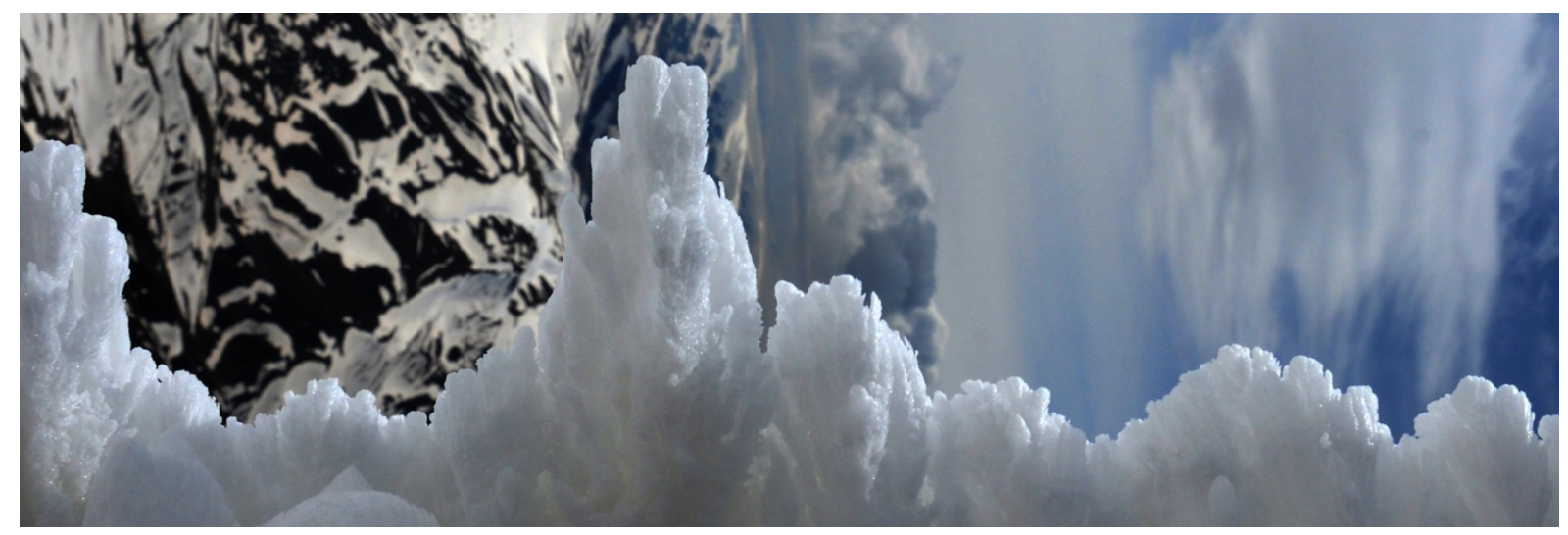

Şekil 4. Uçurumun kenarındaki ışılk (Uzun, 2016).

Işık somutunun algısal üretimine ilişkin teorik bir önerme ortaya koyan Clark \& Paivio (1991, s. 150-155), ikili kodlama teorisi (dual coding theory) adı altında, somutun görsel ve sözel ilişkisinden hareketle zihne kodlandığını savunmaktadır. Sözel semboller, doğadaki somutun karşılıklarını içeren anlamları bilişsele aktarmakta, görsel canlandırma yoluyla sembolün yapısındaki kod açımlanarak somuta ulaşılmaktadır. Sembolik bu yaklaşım, Mead'in (1934), Sembolik Etkileşimcilik Teorisi ile (Symbolic Interactionism Theory) bağıntılıdır. Doğadaki ve insan yaşamındaki her şeyin sembolik açıdan karşılık geldiği bir anlam vardır. Algılama, iletişim ve paylaşım; fenomenolojik sembollerle idare edilmektedir. Sembole dönüştürülen her kod, karşılıklı etkileşimin, üretimin ve fenomenolojik algılamanın anahtarıdır. Bu nedenle somut üzerinde konuşulurken, kastedilen şey çoğu zaman semboller ve onların algısal karşılıklarıdır. Bu durum Gün Geceye Çalarken adlı fotoğrafta görülebilir (Şekil 5). Çünkü gece, fotoğraftaki bir somutluk olarak görgül deneyimle açıklanamaz. 0, somut olarak fotoğrafta yoktur. Ancak bir beklenti olarak ya da bir düşlem olarak vardır. Diyalektik sanatın her zaman çatışmalar ve sentezlemeler ekseninde şekillenmesi beklenemez. Bazen iki taraf arasındaki imgelem sanıldığı kadar anlamlı bir ilişki içinde değildir. Var ve yok arasındaki yakınlık, gündüz ve gece arasında her zaman kurulamaz. Gündüz, gecenin olmadığı bir anın tasviri olmanın ötesinde gecenin varlığındaki bir şeydir. Çünkü her gündüz, bir geceden çıkagelir ve her gece, bir gündüzden. Mutlak determinasyona karşı bir eleştiri olan bu diyalektik tasavvur, öncelik ve sonralık belirlenimlerinin dışında varlığı, somut olmayanla anlatır. Çünkü gündüz somut olarak varken, gece düş olarak vardır. Nitekim bazen gündüz somut olarak varken, düş olarak da vadır. Fotoğrafta bir geceden gündüze geçiş mi yoksa bir gündüzden geceye geçiş mi yaşandığı bilinemez. Esas olan, anlamın sökün yeridir. 


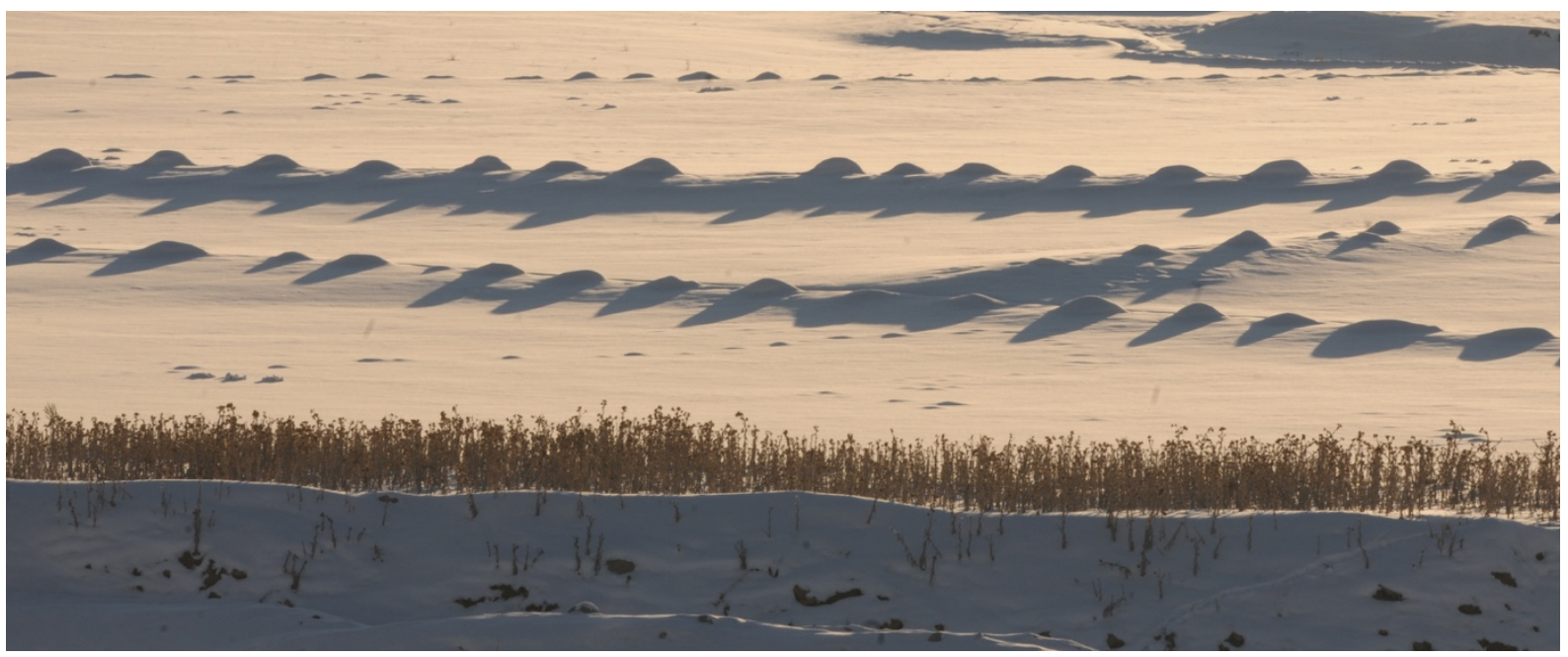

Şekil 5. Gün geceye çalarken (Uzun, 2013).

Hançeroğlu'na göre kelime anlamı olarak somut, hem duyularla kavranan bütünsel gerçeği, hem de bu gerçeğin insan bilincinde gerçekleşen hakikatini dile getiren bir kavramdır (Hançerlioğlu, 1994, s. 376). Buradan yola çıktığımızda insan ve nesne ilişkisini sorgulayabiliriz. İnsanın evrende var olan nesneler üzerinden başlattığı ilişki nesnenin insan için hayati bir önem taşıdığı gerçeğini ortaya koymaktadır. Aynı şekilde nesnenin de insan ile değer kazandığı nesneyi kendi duyu ve görsel hafızasıyla yeniden şekillendirdiği gerçeği ortaya çıkmaktadır. Böylelikle, soyutu somuttan ayıran en belirgin özelliklerin başında görsel algı sürecini konumlandırabiliriz. İnsan hafızasının \%85'ini oluşturan görsel hafıza, bireyin bakış açısına ve tinsel yaklaşımına göre doğada veya evrende ilk algılanmadaki somut objeyi mevcut gerçekliğinden kopararak sanatsal bir nesneye büründürürken soyutlamaktadır. Yani, fenomeno özünden alıp, başka bir öze, yeniye ve özgesel fenomenolojiye büründürmektedir.

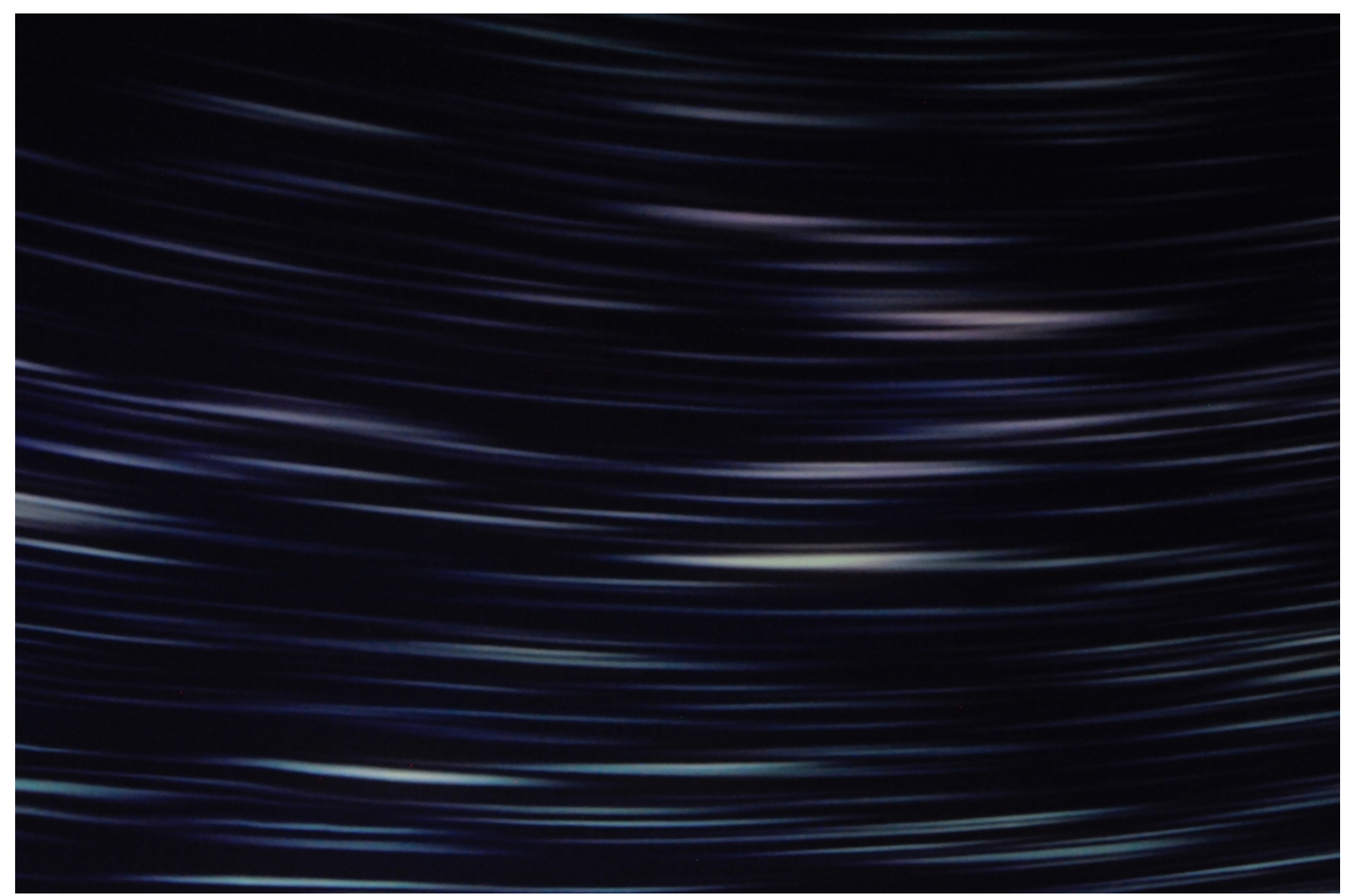

Şekil 6. Yüzeybilim fragmanlar (Uzun, 2019). 
Görsel algı, sadece insan gözünün fizyolojik işleyişi ile sınırlı ve herkes için aynı anlamları yaratan bir süreç değildir. Bu durum Yüzeybilim Fragmanlar adlı fotoğrafta görülebilir (Şekil 6).

\begin{abstract}
Işığın farklı skalalardaki muhtelif görünümleri ile kurgulanan zamansal düzlem ise, gündüzü göstermekle birlikte, gölge yapılarından dolayı net bir şekilde ifade edilememektedir. Doğada özgür olmanın ürkütücü serencamı, doğal ışık-gölge geçişlerine başvurularak aktarılmıștır. Işığın berraklığı, özgürlüğün sonsuzluğuna doğru ilerledikçe, yerini ürkütücü gölge geçişlerine bırakmaktadır. $\mathrm{Bu}$ gölgeleme taktiği, fotoğrafta verilmek istenen mesajı bütünlemesi açısından önemlidir. (Uzun, 2019, s. 89)
\end{abstract}

Aynı olayı birçok kişi farklı algılayabileceği gibi farklı olayların da aynı ya da benzer olaylar olarak algılanması mümkündür. Görsel kodların algılayan kişiye bağlı olarak gösterdiği değişimleri, kişiye ait beklentiler, kişinin ilgi alanları, kişiye ait gereksinimler, kişinin sahip olduğu inançlar ve kişinin daha önce yaşadığı deneyimlerden öğrendikleri olarak sıralanabilir.

Algı, duyu organlarının fiziksel uyarılmasıyla oluşan sinir sistemindeki sinyallerden oluşur. Bireyin algıladığı aslında, nesnenin kendi varlığından çok onun oluşturduğu duyumsal veriler olarak yorumlanabilir. Nesneler hakkında bireyin duyu organları aracılı̆ı ile edinilen verileri algı olarak tanımlayabiliriz. Örneğin, görme gözün retinasına düşen ışıkla, işitme kulağa gelen ses ile oluşur. Algı bu sinyallerin sadece pasif bir şekilde alınması değildir. Fizyolojik, psikolojik ve fiziksel unsurlar, algılama sürecinin ayrılmaz birer parçasıdır. Öğrenme, dikkat, hafıza ve beklenti ile șekillenebilir. Algı, bu yukarıdan aşağıya etkileri kapsadığı gibi duyusal girdinin aşağıdan yukarıya işlenmesini de içerir. Aşağıdan yukarıya işlemler, basitçe, düşük seviye bilgi kullanılarak daha yüksek seviyede bilginin (örneğin şekiller ile nesne tanımada) oluşturulmasıdır. Yukarıdan aşağıya işlemler ile kastedilen, kişinin kavram ve beklentilerinin algıyı etkilemesidir.

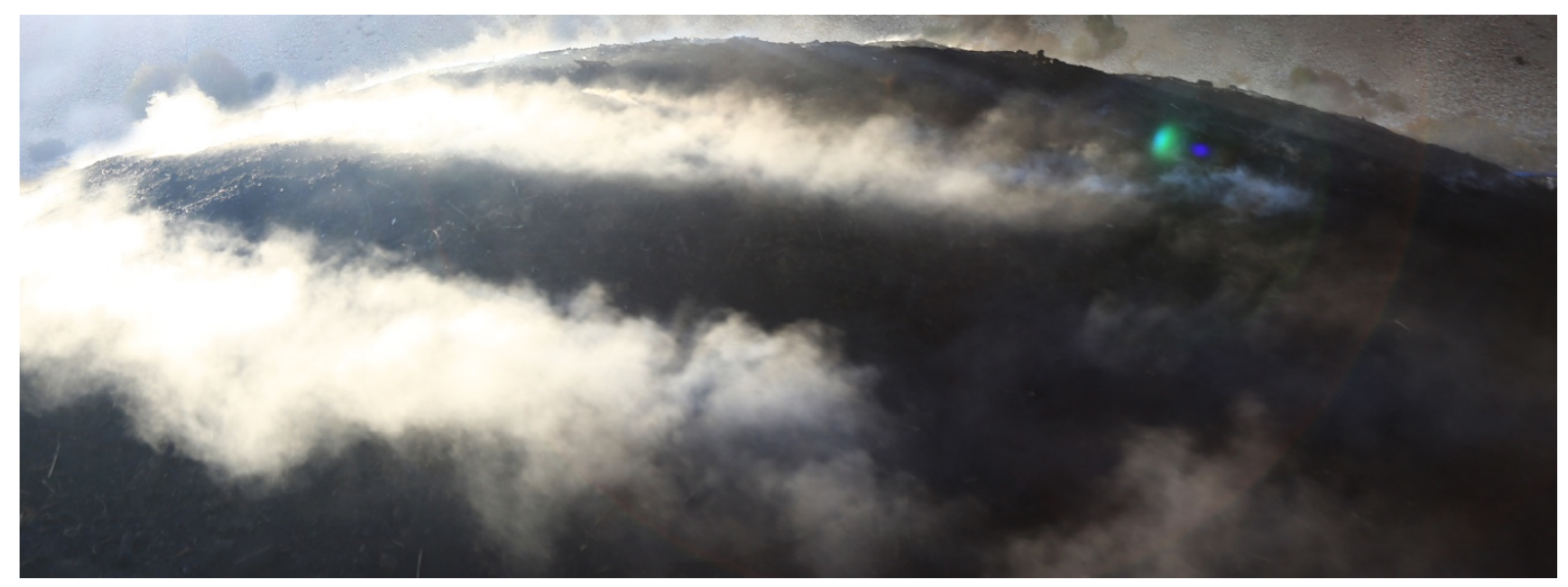

Şekil 7. Uzamdaki spektrum (İsmail Birlik, 2020).

Görsel algl, çevredeki cisimler tarafından yansıtılan görünür spektrumdaki ışığı kullanarak, çevreleyen ortamı yorumlama yeteneğidir. Bu durum Uzamdaki Spektrum adlı fotoğrafta görülebilir (Șekil 7). Böhme (2014, s. 62), modern mimari ve sanatın uzay ve ışık arasındaki ilişkiye dair yaklaşımının fenomenolojik bir çerçevede yorumsamalı (hermenötik) ve düșünsemeli (reflektif) yaratıcıllğa odaklandığını savunur. Beynin, gözlerin gördüklerini anlama yeteneğini ifade eder. Görsel algı da, sadece insan gözünün fizyolojik işleyişi ile sınırlı ve herkes için aynı anlamları yaratan bir süreç değildir. Görme, işlev olarak basit ancak yapı bakımından karmaşık bir süreçtir. Görsel algı için, özelleşmiş çok sayıda beyin bölümünü ve görmenin farklı alt bileșenlerini kullanılır. Diğer duyu ve algılama süreçlerinde de olduğu gibi, bilişsel bir sürecin varlı̆̆ı söz konusudur. Görsel kodların, algılayan kişiye bağlı olarak gösterdiği değişimleri, kişiye ait beklentiler, kişinin ilgi alanları, kişiye ait gereksinimler, kişinin sahip olduğu inançlar ve kişinin daha önce yaşadığı deneyimlerden öğrendikleri olarak sıralayabiliriz. Görerek algılayan bireyin görme süreci, bir fotoğraf makinesi gibi değildir. İmgeye ilk tepkimiz ne kadar otomatik olursa olsun, imgeyi birebir okuma, asla edilgen bir uğraş değildir. Birey, algılayan, yaşayan bir varlıktır (Derman, 2010, s. 29-36). 
İmran Uzun

Görsel imgelerin duygu, heyecanlarımızı uyarma gücü, Antik Çağ'dan bu yana gözlenmiștir. Yalnız imgeler değil, belli çizgi ve renk düzenlemeleri de duyularımız ve dolayısıyla duygularımızı etkileme potansiyeline sahiptir (Gombrich, 2014, s. 138-161). Bu durum, Buzul adlı fotoğrafta görülebilir (Şekil 8).

Suyun bir kütle olarak ışığa karşı direncini betimleyen yüzey gölgeleri, nesnenin kendi üstünde olușturduğu 'bağlı gölge' kategorisinde değerlendirilebilir. Bir iç yansıma ve içgörü olarak bireyin kendiyle kurduğu organik ilişkilere atıfta bulunan bu durum, doğayla bütünleșen varlığın kendi koşullarını yaratması ve benzeşmesi olarak kodlanabilir. Doğayı kendine benzetme ya da doğaya benzeme arayışındaki insanın her iki durumda da yeniden biçimlenmesi kaçınılmazıdır. Su yüzeyindeki kabarcıkların yaşamı simgelediği anlatıda, iç içe geçmiş balık suretlerinin içinde bulundukları suyla kaynaşarak biçimlerini kaybetmeleri ve suyun bir uzvuna dönüşmeleri anlatılmaktadır. Yaşamın doğa ile iç içe olması, insanın da doğaya ait olduğu anlamına gelir. Bu nedenle insan yașayabilmek için doğanın parçası olmak zorundadır. İnsan doğayı kendi suretinde dönüştürmeye başladığında kendine yabancılaşmaktadır. İnsanın doğa içindeki varlığı ise biyografik bir kimliklenmedir ve doğa insana kim olduğunu gösteren bir kılavuzdur. (Uzun, 2019, s. 77)

Gerçekliğin algılanmasında tüm duyumlar birlikte iş görürler ve birbirlerini denetlerler, ancak temel algı görsel algıdır. Görme işlevleri normal olduğunda, bilinç düzeyindeki davranışlarımızın büyük bölümü için görsel algılarımız belirleyici öge olmaktadır (Derman, 2010, s. 29-36).

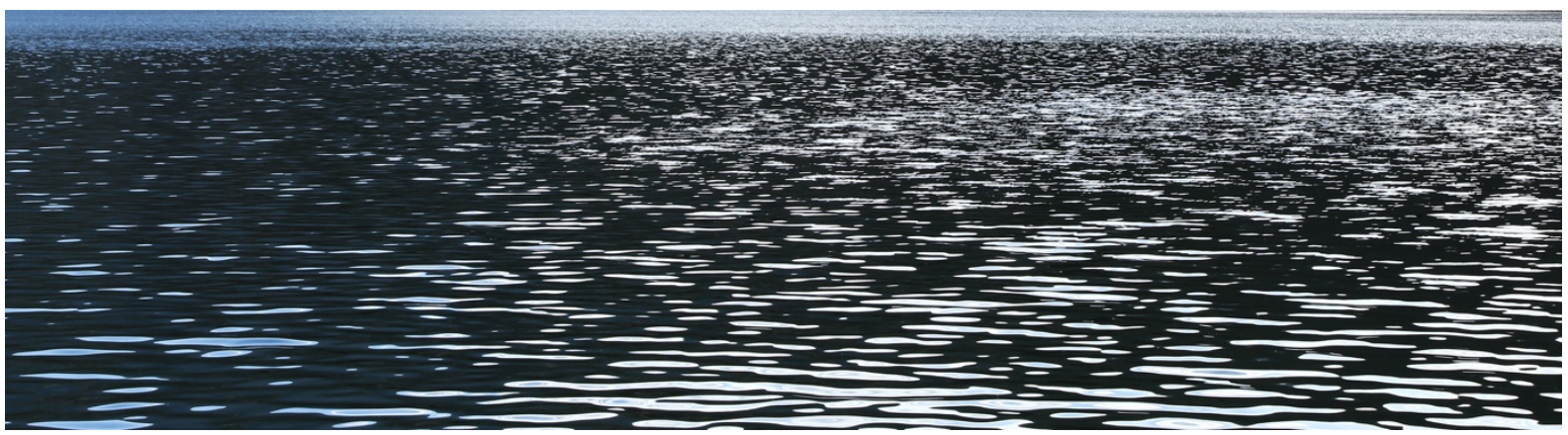

Şekil 8. Buzul (İsmail Birlik, 2019).

Nesnelerin algılanabilir özellikleri ve kendi özellikleri arasındaki ayırım, bu nesnelerin değișik zamanlarda farklı olarak algılanmalarına da yol açmaktadır. Görsel nesneler, en azından perspektif yüzünden değişikliğe uğrar ve farklı şekillerde algılanabilirler. Görünür boyut ve biçimleri, nesnelerin ve algılayanın konumuna göre farklılaşır. Ancak farklılaşan tüm algılar, yine algısal ipuçları sayesinde bilinç katında dengelenir ve nesnelerin kalıcı, bilinen özelliklerine göre düzeltilir. Bireyin içinde yaşadığı kültürel ortam, algılarının bir başka belirleyicisidir. Toplumsal gerçekliğin, bireysel gerçekliği etkilemesi bununla ilișkilendirilebilir. Sonuç olarak, gerçekliğin bir anlamda yeniden sunumunu oluşturan algılar, algılananın fiziksel özellikleri, algllayanın fizyolojik, psikolojik, kültürel özellikleri ile bu algıların içinde gerçekleştiği ortamın toplumsal, kültürel özellikleri ile biçimlenmektedir. Tüm bunlar, nesnelerin algılanabilir özelliklerinin farklı kişilerce farklı değerlendirilmesine yol açmaktadır. Gerçeklik hakkında edinilen bilgiler, nesnelerin algılanabilir özellikleri ile bu özelliklerin çok sayıda farklı etmenler ile her bireyin zihninde değişik şekillerde yorumlanması sonucunda toplanmaktadır (Derman, 2010, s. 29-36).

Sanatçllar, düşünürler, fizik bilimciler, psikoloji ile ilgilenen bilim insanları, çok uzun yıllardır insanın fenomenolojik görsel dünyasını belirlemeye ve anlamaya çalıştılar. Son yıllarda, sanat ve bilim arasında giderek artan düzeyde, disiplinler arası önemli etkinlikler görüldü, birçok bilim insanı sanatın nasıl yapıldığına ve takdir edildiğine dair yeni bilgiler edinmek için kendi alanlarındaki bilgi ve yöntemleri uyguladılar (Pepperell, 2011). Bazı bilim insanları, fikirlerini ve yaklaşımlarını paylaşmak için sanat tarihçileriyle yakın işbirliği içinde çalışmaya başladılar. Bu yeni işbirlikçi ruhu motive eden etmenlerden biri, bilim insanları tarafından araştırılan, insan beyninin nasıl çalıştığı konusunda, sanatçıların da bazı keşiflerde bulunduklarının anlaşılması oldu. Özellikle görsel işlevlere yönelen bașta ressamlar olmak üzere birçok sanatçının nörolojik bilimler alanına katkı verdikleri konuşulmaya başlandı. Yüzyıllar boyunca, sanatçıların, yoğun olarak, dünyanın algılanma şekli üzerinde çalışmakta oldukları göz önüne alındığında, örneğin nesneleri, rengi, formu veya derinliği fenomenolojik olarak algılayışımız ile ilgili bazı yolları anlamış 
olmaları sürpriz değildir. Gözlemleri aracılığıyla, sanatçılar, tüm dünyada, müzelerde ve galerilerde sayısız sanat eserinde, bulgularının kalıcı bir kaydını bıraktılar. Tüm bu biriktirilmiş sanatsal bilgileri açmak, algı ve biliş konusunu bilimsel olarak anlayışımız ile bağdaştırmak görevi, uçsuz bucaksız ve aynı ölçüde muazzamdır. Bu nedenle sanat ve bilimin işbirliği içinde çalışması, kültürlerarası ve metodolojik büyük zorluklara rağmen memnuniyetle karşılanmaktadır. Nitekim Gertz'e göre (2010, s. 42-43) natürel tavır ile kavramsal tavır arasındaki diyalektik, karşılıklı savaşımın sonucunda yaratıcı bir eylem olan barış ile sonuçlanır ve uzlaşmış bir fenomenolojik eylemin sanat kadar bilime de katkısı düşünülebilir.

\subsection{Işığın Duyusallığı ve Duyumsanan Sanatın Öznel Belirsizliği}

Görsel algının ilk aşaması, görme duyusuyla başlar. Görme duyusu, göze dayalı olarak işleyen bir algılama sistemidir. İnsan algısının \%80'inin görsel algıya dayandığı söylenir. Bu nedenle gözler, insan algısının en önemli organıdır. Hatta insan vücudunun duyu algılayıcılarının \%70'inin gözdeki retina tabakasında olduğu ileri sürülmektedir.

Fakat, görsel algıyı sadece göz ve gözün işleyişiyle sınırlandırmak neredeyse imkansızdır. Çünkü nesnelerin fiziksel görüntüsü kadar, gören kişinin psikolojik durumu, nesne ile olan mesafesi, daha önce o nesne ile olan ilişkisi gibi birçok konu, görsel algının kapsamına girer ve bireylerin algısal etkinliklerinin düzenlenmesinde belirleyici rol oynarlar.

İnsan gözü, kafatasında kemikten oluşan bir yuva içinde bulunur ve bu yuva içindeki yağ dokusu tarafından sarılmış durumdadır. Göze bağlı bulunan 6 farklı kas gözün hareketini sağlar.

Gözün işlevini yerine getirmesi için öncelikli olarak ışığa ihtiyacı vardır. Bizler için ışık, görebildiğimiz dalga boylarından ibarettir. İnsan gözünün göremediği dalga boyları da mevcuttur; fakat insan gözünün yapısı ancak görülebilir ışık tayfıyla sınırlıdır. Görülebilir ışık tayfı da renklerden oluşur. CIE (Comission Internationale de l'Eclairage), $380 \mathrm{~nm}$ ile $780 \mathrm{~nm}$ arasındaki dalga boylarını 'görülebilir' olarak belirlemiştir (International Commission On Illumination, 2020). Bu görülen ışığın 380 nm'den (mavi) 780 nm'ye (kırmızı) değişen birleşimleridir.

Nesnelerin üzerlerinden yansıyan ışıklar, önce gözdeki kornea tabakasına gelirler. Kornea, gözün en üst katmanını oluşturan parlak yüzeydir. Yaklaşılk olarak 0,5 mm kalınlığında ve $12 \mathrm{~mm}$ çapındadır ve göze gelen ışınların en fazla kırıldığı bölümdür. Ayrıca, gözün nesneleri net bir şekilde görmesinde en büyük rol korneaya aittir.

Arbib ve Hanson gibi kuramcılar, görmeyi iki farklı şekilde ifade ederler. Bunlardan ilki, sadece basit bir duyum olarak ön süreçleri içeren düşük düzey görmedir. Diğeri ise daha önce elde edilen deneyimlere ait bilgileri kullanarak görmeyi ifade eden üst düzey görme olarak adlandırlır. Bu tanıma çok yakın olan görmek ve bakmak adları adı altında iki kavram da halkımız tarafından sıklıkla kullanılır. İște bu noktada, algısal bir etkinlik olarak görme ve duyusal bir etkinlik olarak görme farklılıkları ortaya çıkar (Altunay, 2009, s. 76-78).

Her algısal deneyimin bir nesnel ve öznel bir tarafı vardır. Duyum ve duyguları temsil eden öznel yönü ve anatomik ve fizyolojik süreçler ile gelişen nesnel yanı olarak iki kısım şeklinde düşünebiliriz. Görsel sanatı işleyen araç olan görsel sistem, görsel sistemimize akan çok büyük miktarda veriyi filtrelemeyi, düzenlemeyi ve sıralamayı hedeflemektedir (Aviv, 2014). Görsel işlemenin erken aşamalarında, görsel işlev alanı, ışık noktaları, çizgiler, kenarlar, basit formlar, renkler, hareket gibi temel bileșenlerine dönüştürülür. Daha sonraki aşamalarda ise, sistem bu bileșenleri karmașık formlara ve nesnelere dönüștürür: hareketli bir araba, gözlerini kırpan yüz, bir dansçının parmak uçlarında dönmesi gibi. Bu sürekli devam eden süreçler, dünya hakkında bilgi sahibi olmamızı, hızlı ve etkili genellemeler yapmamızı ve kararlar almamızı sağlamaktadır.

Eski Yunan'da ve Rönesans Avrupası'nda sanatçılar, birkaç kuşak boyunca imgelerini görülür dünyaya adım adım yaklaştırmaya, tam bir benzerliğe ulaşmaya çalışmışlardır. Birçok eleştirmenin bu başarıya duydukları hayranlık, günümüzde eski coşkusunu yitirmiştir. Antikçağ dünyası, sanatın evrimini temel olarak teknik bir ilerleme gibi taklit etme, mimesis becerisine egemen olma gibi görüyordu. Sanat yoluyla gerçekliğe egemen olma süreci, hızı değişerek, en azından 19. yüzyıla kadar sürmüş ve izlenimcilerin verdikleri savaşlar, görsel keșif konusu üzerine verilmiştir (Gombrich, 2014, s. 138-161). Günlük nesnelerin işlenmesinin aksine, görsel sanatlar, günlük yaşamımız boyunca görsel sisteme uygulanan işlevsel kısıtlamalardan arındırılmıştır. Sanat, nesneleri ve sahneyi organize etmek ve temsil etmek için yeni yollar bulmakla meşgul olmaktadır. Sanatçllar, tasvir edilen nesneleri işlevsel olmayan çeşitli şekillerde temsil etmek ve ayrıştırmak için serbesttirler. 
Görsel belirsizlik, izleyiciye, kolay ya da anında tanınmaya olanak vermeyen, görünüște anlamlı bir görsel uyaran sunulduğunda ortaya çıkan algısal bir deneyimdir (Pepperell, 20011). Bu tür bir görüntü ile yüzleşme, neyin tasvir edildiğini belirleme ihtiyacı uyandırır ve bu yüzden bilmeceyi çözmek için ek dikkat gösterilir. Belirsiz görüntülerin cazibesi, izleyicilerini şaşırtmak, kafalarını karıştırmak için kapasitelerini sıklıkla kullanan sanatçıların dikkatinden kaçmadı. Sanatta tanımlanamayan imgeler ile ilgili ilk çalışmada, Gamboni (2002), sanat tarihine derinlemesine uzanan eserlerde, sanatçıların kasıtlı olarak resimleri içine değişik öğeler veya parçalar koyma yolu ile izleyicilerinin gördüklerini tanımlama kapasitelerini zorlama yollarını araştırarak, belirsizliğin kullanımının izinlerini aradı. Görsel alan içerisinde gösterilmeyen ışık kaynağı kaynağın ne olduğuna dair gizem yaratır ve yoruma açıktır. Bu durum gizem, ruhanilik, korku, endișe, terör gibi farklı psikolojik etkiler oluşturmak için kullanılmıştır (Karavit, 2006, s. 16-17; 22).

On sekizinci yüzyılın sonlarında Joseph Wright tarafından yapılan Bir Hava Pompası içindeki Bir Kuş Üzerinde Deney (Experiment on a Bird in an Air Pump) adlı bir çalışmada (National Gallery London, 1768) bunun ünlü bir örneği bulundu. Bu durum Experiment on a Bird in an Air Pump adlı fotoğrafta görülebilir (Şekil 9). Resimde, oksijen yoksunluğunun bir kuş üzerindeki etkisinin bilimsel bir gösterimi betimlenmektedir ve ana hatlarıyla kusursuz bir netlik ile sunulmaktadır.

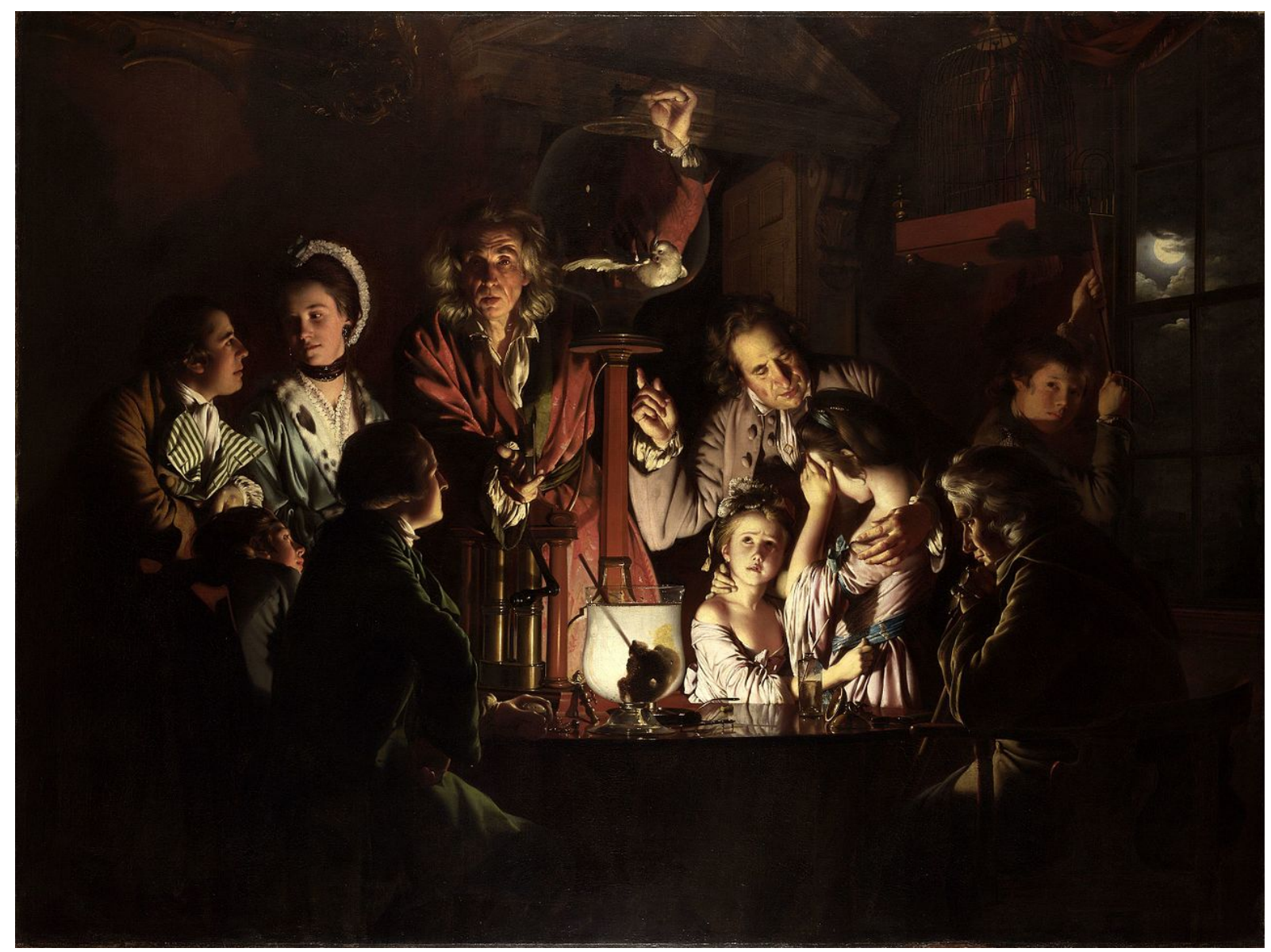

Şekil 9. Experiment on a bird in an air pump, Joseph Wright, 1768.

Görsel belirsizliğin sanatsal olanaklarından yararlanmak için, sınırları daha fazla zorlamış bir sanatçı, 19 . yüzyılın erken dönemlerinde romantik akımları izlemiş, atmosferik ortam manzaraları ve deniz manzaraları ile ünlü İngiliz ressam J. M. W. Turner'dir. Şimdi çok ünlü olmasına rağmen Turner, yaşamı boyunca, okunaksız ve belirsiz görülen işler ürettiği için sık sık ağır eleştirilere uğradı. 0 dönemde Turner'in, herkese açık bir şekilde sergilediği ve en yüksek sesle eleştirilen işlerinin şu an bize gayet açık ve belirgin görünüyor olması ilginçtir.

Eleştirmenler, Turner'ın halka açık göstermediği 1830'larda yapılmış Büyük Evin İçi: Çizim Odası (Interior of a Great House: The Drawing Room), East Cowes Kalesi (East Cowes Castle) gibi eserlerinden bazılarını görmüş ve çok şaşırmışlardı. Hala resimlerin konusu tam olarak anlaşılamamıştır, hatta yakından incelendiğinde bile, bir kısmı dışında, betimlenen nesnelerden anlam çıkarmak mümkün olmamaktadır. 
Onu bu tür işler üretmeye zorlayan Turner'in zihninde ve daha tanınabilir eserlerini dahi anlayabilmek için mücadele veren halkın zihninde neler olduğunu bilmek güçtür. Bununla birlikte, bugün biliyoruz ki, Claude Monet, ilk kez 30 yaşında iken Londra'ya gittiğinde, Turner'in eserlerini görmüș ve ondan etkilenmiștir. Monet daha sonra, 1872'de, Turner'dan etkilenerek, İzlenim, Gündoğumu 'Impression, Sunrise' adlı eserini yapmıș, 1874'de sergilenen eser, empresyonizm akımına adını vermiștir. Le Havre Limanı'nın sisin içindeki bu oldukça kabataslak görüntülenmesi, özellikle çağdaşı bir eleștirmeni kızdırmış, resimdeki belirsizliği küçümsemiş "Bu kanvas ne gösteriyor?" șeklinde alaycı sorusunu sormuştur. Aslında, Monet'nin resmin işlevi konusunda ilgilendiği, dünyanın görünümünü gizlemek değil, içtenlikle, doğrulukla betimlemekti. Farklı bir deyişle, orada gözlerinin önünde duran ile ilgili ne bildiğini değil, ne gördüğünü yansıtmak istedi. Kendisinin1890'larda Rouen Katedrali'nden yaptığı birçok manzaradan biri gibi bir tablo, katedralin duvarlarının kendisinin bu duvarlardan yansıttığı ışıktan daha çok betimlenmesi değildir. İzleyici olarak bize kalmış olan, Monet'nin dönemindeki sanatçılar arasında popüler olan görme teorilerine göre, katedralin ışık formundaki desenini, kendi kavramsal kaynaklarımızı kullanarak okumaktır (Pepperell, 2011).

İlerleyen yıllarda Avrupa sanatına soyutlama kavramını getirerek itibar kazanacak olan Rus sanatçı Wassily Kandinsky, 1895'te Moskova Galerisi'nde, Monet'nin güneşte saman yığınlarını betimleyen resim serilerinden birini gördü. Resmin ne olduğunu anlayamadı, daha sonra şöyle anlattı:
Ve aniden ilk kez bir resim gördüm. Katalog, bir samanlık (ya da daha doğrusu bir tahıl yığını) olduğu konusunda bana bilgi veriyordu. Tanıyamadım ve şaşkınlıkla, hayret içinde, resmin beni sadece yakaladığını değil, aynı zamanda hafızamı da kaçınılmaz köklü bir şekilde etkilediğini fark ettim. Resim bir masal gücü ve görkemi gösterdi ve bilinçsiz de olsa, nesneler resmin içinde temel bir unsur olarak gözden düştü. (Parsons \& Gale, 1992, s. 255).

Benzer bir deneyim Kandinsky'nin Hatıraları'nda 'Reminiscences' bir pasajda anlatılmaktadır. Gece karanlığında atölyesine döndüğünde, duvara dayalı duran 'içinden bir ışık yayılan tarif edilemez derecede güzel bir resim' gördüğünde hayret etti. İçinde sadece formları ve renkleri ayırt edebiliyordu ve anlaşllabilir hiçbir nesneyi göremiyordu. Aslında, nesnesini tanıyamadığı kendi izlenimsel resimlerinden biriydi. Kandinsky, nesnesiz görüntülerin dikkat çekici bir algısal yanıt uyandırma potansiyeli olduğunu fark etti. Daha sonra, bu anlayışın ifade edilebileceği görsel bir dili geliştirmek için yıllarını harcadı. Çağdaş sanatçılar arasında Gerhard Richter, oldukça farklı stillerde çalıştığı için biraz sıra dışıdır (Pepperell, 2011).

Hem kesin olarak işlenmiş fotoğrafa benzeyen resimler, hem de nerdeyse tesadüf eseri kazıma işlemi ile üretilmiş daha büyük soyut çalışmaları ile tanınır ve nihai etkiyi boya ve araçlar arasındaki öngörülemeyen etkileşime bırakır. Ancak geleneksel anlayış içinde gerçekçi ya da soyut olarak görülmektense, temsili olmayan anlayıșta, Richter'in çalışmaları, burada anlatılan şekilde belirsiz olarak daha iyi anlaşılabilir. Sanatçının üretmeye çalıștığı şey, izleyiciyi gördüklerini denemek ve çözmek için çeken bir belirsizlik duygusudur. Richter kendisi bu konuda çok açıktır ve şunu söyler;

Yorumlanabilir ve anlam içeren resimler kötü resimlerdir. Öte yandan iyi bir resim, sınırsız görüş çeşitliliği içerir, çünkü anlamından ve isminden yoksundur. Bize, tek bir anlamın veya görüşün ortaya çıkmasını engelleyen tüm değişik anlamların içindekini ve sonsuz çeşitliliğ̆i gösterir. $\mathrm{Bu}$ değişimde sanat eleştirmeni Robert Storr, belirsiz algı kuramı ile ilgili fikrini şöyle açıklıyor: Tabloda bir masaya veya başka şeylere benzeyen bir şeyden kaçınmaya çalıșıyorum, böyle olduğu zaman görebileceğiniz tek șey bu nesne. (Storr, 2003)

\section{Sonuç}

Karanlık Kutu (Camera Obscura), dört tarafı da ışık sızdırmayacak biçimde kapatılmış bir kutu içerisinde, bir iğne deliğinden giren ışık yardımıyla görüntü oluşumunu sağlayan basit bir aygıttır. Karanlık kutu içerisindeki hayali görüntü, alt-üst ve sağ-sol ters olarak oluşur. Görüntünün büyüklüğ̈̈̈, kullanılan karanlık kutunun büyüklüğüne, delik çapına, deliğin açıldığı yüzeyin kalınlığına ve nesnenin aydınlanma şiddetine bağlıdır. Karanlık kutu içerisinde görüntünün oluşumuna yönelik ilk bilgiler, M.Ö. V. yüzyılda yaşamış Mo Ti tarafından ortaya konulmuştur. Daha sonraki yüzyıllarda Aristotales, İbnü’l Heysem, Leonardo Da Vinci ve birçok bilim insanı, bu aygıtın çalışma prensibi üzerinde araştırmalar yapmış ve bunlardan bazıları, bu aygitın bir resmetme aracı olarak kullanılabileceğini belirtmiştir. Karanlık kutu üzerinde açllan deliğin önünde mercek kullanılması, elde edilen görüntünün kalitesini artırmış ve bu aşamadan sonra özellikle 
nesnenin görüntüsünü tam bir doğrulukla yüzey üzerine aktarmak isteyen ressamlar tarafından kullanılmaya başlanmıştır.

Daniele Barbaro'nun diyaframı, Johann Cristoph Sturm'un $45^{0}$ açılı aynası ve Johann Zahn'ın kısa ve uzun odaklı mercek sistemi de eklenince karanlık kutu daha işlevsel hale gelmiştir. Bu aşamadan sonra sadece dönemin ressamları tarafından değil aynı zamanda bilimsel çalışmalar da, eğitim ve eğlence amaçlı gösterilerde de yaygın olarak kullanılmaya başlanmıștır. Karanlık kutu, ışık yoluyla yüzey üzerinde görüntü üreten optik bir aygıttır. Görüntünün varlığı, ışığa bağımlı olduğu için, bu aygıt tarafından oluşturulan görüntünün temel karakteri, hayali bir görüntü olmasıdır. Karanlık kutu, çevremizi saran nesneler dünyasının aslına sadık tam bir kopyasını yüzey üzerinde görüntü olarak üretebilen bir aygıttır. Bu nedenle, insan gözü ve algılamanın doğası hakkında yepyeni bilgilere ulaşılmasında önemli katkıları olmuştur (Turan, 2013, s. 25-26).

Işık söz konusu olduğunda onu daha iyi anlamak adına algısal inşa fonksiyonlarından da bahsetmek gerekir. Çünkü algısal fonksiyonlar fotoğraf çekiminde fotoğrafçının iyi bir fotoğrafta ihtiyaç hissettiği öğeleri oluşturur. Işığın iyi fotoğraf üzerindeki algısal fonksiyonları konuyu ortaya çıkarması, konuda aydınlık ve gölge alanlar oluşturması ve dokusal zemini ortaya çıkarmasıdır. Bu özellikler zaten iyi bir fotoğrafın oluşabilmesi için gerekli olan öğelerdir (Kanburoğlu, 2012, s. 64-66).

Fotoğrafçılığın geneline baktığımızda bir ışık okulu, bir ışığı yüzey üzerine kaydetme laboratuarı olarak değerlendirmek zorundayız. Fotoğraf, ıșığın doğal ya da yapay kaynaklardan gelen enerjiyi kontrollü bir şekilde kaydetme sanatıdır. Gündoğumu, günbatımı, mevsimsel ışıkları, bölgesel yani Kuzeydeki sisli yumuşak ışık, Güneydeki kızgın ve ezici ışık ve birçok sanatçının peşinde olduğu, on iki saatlik zaman diliminde ve güneşli havalarda yakalanabilen 'altın ışık' günün sadece çok kısa bir bölümünde algıyla buluşur. Fotoğrafa renkli olarak baktığımızda günbatımında, kızmıș ve artık soğumaya bașlamıș olan bir ışık kaynağının oluşturduğu bir saatlik bir zaman diliminde, kompozisyonu algısal katmanlarda örgütlemek gerekir. Çok önemli iki saat birbirinden en az on saat uzak iken, onların yakınlığı ve uzaklığı arasındaki mesafe, algısal bir opsiyonla yeniden düzenlenebilir ve ışığın taşıdığı değerin çok daha ötesine geçilerek ışık üstü bir eser oluşturulabilir. Fotoğrafta ıșık yolculuğu, görsel algının tüm kademelerinde izdüşümlerini ve düşünsel tayflarını oluşturan uzun soluklu bir yolculuktur.

Algılanan yüzey üzerine bir ışık huzmesini kaydetmek kendi başına yeterli değildir. Kötü koşullarda bir hapishanede bırakmak gibi bir şeydir. Dolayısıyla teknik olarak kaydettiğimiz ışık, algısal olarak inşa edilen belli kompozisyonlarla desteklenmeli, konularla anlamlandırılmalı ve içeriğe sahip olmalıdır. Fotoğraf albümleri görsel hatıra defterleri gibidir. İnsan albümündeki herhangi bir fotoğrafa baktığı zaman, o dönemi anımsatan bir algısal yoklama yapması ve bir iki sözcük söylemesi kaçınılmazdır. Devamlılık arz eden durumlarda sanki hatıra defterinden satırlar okuyormuşçasına anlatılar devam edecektir. İște bu yüzdendir ki fotoğrafın algısal bir dili vardır. Fotoğrafçı, kareleri ikinci veya üçüncü şahıslar tarafından izlenildiğinde ressamlara ve grafikerlere sorulan sorularla çok karşı karşıya kalmaz.

Saf ışıkta çektiğimiz temsili gerçekler üzerine düşen algısal ıșık, ustaların ve hocaların da dediği gibi "beklenen o anda, fotoğrafçıların çektiği fotoğrafları sadece fotoğraf olmaktan çıkarıp anlamlandıran güneşin sanatsallaştırdığı bir esere dönüştürür" (Kanburoğlu, 2012, s. 48). Işı̆̆ın Ressamı olan Monet'in atölye ressamlığını kesin bir dille reddetmesinin gerekçesi olarak aktardığı şu bilgi gün ışığını veya doğal ışığı takip ederken bizlere gerçeğin nasıl olması gerektiği konusunda deneyimlerini ve çalışmalarını aktarırken "açık havada yapılan eskizlerin atölyede aktarımı sırasında ressamların hiçbir zaman o ana yoğunlaşamadığı, hep motiflerinin özünü aramaya çalıştı̆̆ı” görüşündeydi (Krausse, 2005, s. 74-75). Bu ise resimlerinin hep fazla stilize olmasına yol açıyordu. Oysa İzlenimci resim, bir anın gerçeğinin yakalanmasıdır. Bu nedenle sanatı 'gerçekçi' olarak da adlandırmıştır.

Sonuç olarak imajları deşifre etmeyi zorlaştıran sanatçılar, bunu sadece kasıtlı olarak gizlemek veya izleyicilerini şaşırtmak için yapmamaktadırlar. Aynı zamanda bazı görüntülerin görsel sistem ile nasıl etkileştiğini ve dünyayı nasıl anlamlandırdığımızı keşfederek görme ve algı üzerinde çalışan bilim insanları gibi davranmaktadırlar. Genelde sanat, özelde ise görsel sanat, beynimizi gerçekliğin egemenliğinden kurtarmakta, içsel durumlarının içinde akmasına izin vermekte, yeni duygusal ve bilişsel birliktelikler yaratmakta ve başka türlü erişilmesi daha zor olan beyin durumlarını aktive etmektedir (Aviv, 2014). Bu süreç, izleyicinin beyninin henüz keşfedilmemiş iç bölgelerinin keşfedilmesini sağladığı için, görünüşe göre faydalı ve değerlidir. İnsanlar duvarın üstünden atlayıp doğaya çıkınca güneş ışığı gözlerini kamaștırır ve her şeyi net ve gerçekliği ile görür. Gün ışı̆̆ına çlkınca aydınlanmış, bilgelenmiş, gerçeğe kavuşmuştur. Burada ışık kaynağı; aydınlanmanın, bilgilenmenin, gerçekliğe ulaşmanın simgesi olarak rol oynar (Karavit, 2006, s. 23-24). 
Fotoğraf gerçekliği her şeyden önce, tekniğin öznelliği ve tikel bir amaca hizmet etmek üzere kullanılması fikriyle açıklanabilir. Çünkü fotoğrafın sanatsallığı, teknik ile iç içedir. Flusser'a göre (2009, s. 11-12), ontolojik bakımdan geleneksel görüntüler görüngüleri kastederken, teknik görüntüler kavramlara gönderme yapar. Fotoğraf bir teknik görüntüdür, çünkü aygit/aparat kullanılarak elde edilmektedir. Fenomenler dünyasındaki mekanik bir gezinme ve bir șeyleri çekip alarak kendine ayırmadır. Bu nedenle fotoğrafı duvar ya da tuvale nakședilen resimlerden ayıran kavramsal bir yönün varlığı söz konusudur. Çünkü resim bir yansıma ve olgusal olanın 'renkli gölgelerinin' aktarıldığı bir sanat iken, fotoğraf ise olguların kavramsal yönlerinin düğümlendiği ve çözüldüğü bir sanattır. İnsan ile doğa arasındaki koşulsuz bütünleșmenin ve organik aktarımın karakterinde bulunan kavramsallık, fotoğraf makinesinin teknik aracılığında yeniden vuku bulur. Kavramların felsefi boyutunu aşkınlık düşüncesine bağlı kılmak ya da nesnel bir hakikat arayışında olmak arasındaki ince modernist çizgi, tekniğin insanın bir uzantısı olarak doğayı kavrayabildiği fotoğraflama süreçlerinde giderek öznelleşir. Makinenin işlevleri böylece insansı nitelikler kazanır ve gerçekliğin öznel bakışına uzanan bu meşguliyette, tekniğin protez olma özellikleri de çözünür. Geriye kalan ise, fotoğrafın tam anlamıyla kestirilemeyecek kadar karmaşık, ancak gerçeğe ikizi kadar benzeyen basit yapısallığıdır.

\section{Kaynakça}

Altunay, A. (2009). Görsel estetik. Eskişehir: Anadolu Üniversitesi.

Aviv, V. (2014). What does the brain tell us about abstract art? Frontiers in Human Neuroscience, 85(8), 1-4. Barthes, R. (2008). Camera lucida: Fotoğraf üzerine düşünceler (R. Akçakaya, Çev.). İstanbul: Altıkırkbeş.

Böhme, G. (2014). Light and space. On the phenomenology of light. Dialogue and Universalism, 24(4), 62-73.

Brash, E. (1983). The art of photography. Virginia: Time-Life.

Clark, J. \& Paivio, A. (1991). Dual coding theory and education. Educational Psychology Review, 3(3), 149210.

Colebrook, C. (2013). Gilles Deleuze (C. Soydemir, Çev.) [3. Baskı]. Ankara: Doğu Batı.

Derman, İ. (2010). Fotoğraf ve gerçeklik. İstanbul: Hayalbaz.

Eco, U. (1989). The open work (A. Concogni, Trans.). USA: Harvard University.

Flusser, V. (2008). Bir Fotoğraf Felsefesine Doğru (İhsan Derman, Çev.). İstanbul: Hayalbaz Kitaplı̆̆ı.

Foucault, M. (1994). Kelimeler ve şeyler (M. A. Kılıçbay, Çev.). Ankara: İmge.

Gamboni, D. (2002). Potential images: ambiguity and indeterminacy in modern art. London: Reaktion.

Gertz, N. (2010). On the possibility of a phenomenology of light. PhaenEx, 5(1), 41-58.

Gombrich, E. H. (2014). İmge ve göz. Görsel temsil psikolojisi üzerine yeni incelemeler (K. Atakay, Çev.). İstanbul: Yapı Kredi.

Habermas, J. (1993). İdeoloji olarak teknik ve bilim (M. Tüzel, Çev.). İstanbul: Yapı Kredi.

Hall, S. (1997). The work of representation: cultural representations and signifying. London: Sage.

Hall, S. (1999). İdeolojinin keşfi: Medya çalışmalarında baskı altında tutulanın geri dönüşü. M. Küçük (Der.), Medya, İktidar, İdeoloji içinde (s. 77-126), Ankara: Bilim ve Sanat.

Hançerlioğlu, O. (1994). Felsefe sözlüğü. İstanbul: Remzi.

İkizler, E. (2003). Temel fotoğraf. İstanbul: Fotoğrafevi.

International Commission On Illumination. (2020, 12 Aralı). CIE publications - premium source for knowledge on light and lighting. Erişim adresi: http://cie.co.at/publications/internationalstandards

Kanburoğlu, Ö. (2012). Fotoğrafin büyüsü: Işılk. İstanbul: Say.

Karavit, C. (2006). Işılk gölge. İstanbul: Telos.

Krausse, A. C. (2005). Rönesastan günümüze resim sanatının öyküsü. İstanbul: Literatür. 
Levoy, M. S. (2011, 8 Mart). History of photography as art. Erişim adresi: https://graphics.stanford.edu/courses/cs178/lectures/history3-art-06may14.pdf

Mead, G. H. (1934) Mind, self and society. Chicago: University of Chicago.

Nedjadrasul, D. (2017). Abstract and concrete consepts according to word association (Master's thesis). University of Western Ontario, Canada.

Paivio, A. \& Csapo, K. (1969). Concrete image and verbal memory codes. Journal of Experimental Psychology, 80(2), 279-285

Parsons, T \& Gale, I. (1992). Post-impressionism, the rise of modern art 1880-1920. London: Studio.

Pepperell, R. (2011). Connecting art and the brain: An artist's perspective on visual indeterminacy. Frontiers in Human Neuroscience, 84(5), 1-12.

Snyder, J. \& Allen, N. W. (1975). Photography, vision and representation. Chicago Journals, 2(1), 143-169.

Sontag, S. (1993). Fotoğraf üzerine (R. Akçakaya, Çev.). İstanbul: Altıkırkbeş.

Storr, R. (2003). Gerhard Richter: Doubt and belief in painting. New York: Museum of Modern Art.

Turan, E. (2013). Fotoğraf tarihi, fotoğrafın tarih öncesi. Eskişehir: Anadolu Üniversitesi.

Uzun, İ. (2019). Fotoğraf sanatında soyutun inşası (Sanatta Yeterlik Tezi). Atatürk Üniversitesi Güzel Sanatlar Üniversitesi, Erzurum.

Wicks, R. (1989). Photography as a representational art. British Journal of Aesthetics, 29(1), 1-9.

Wright, J. (1768). Experiment on a bird in an air pump [Resim]. The National Gallery, London. Erişim adresi: https://www.nationalgallery.org.uk/paintings/joseph-wright-of-derby-an-experiment-on-a-birdin-the-air-pump

Worringer, W. (2017). Soyutlama ve özdeşleyim (İ. Tunalı, Çev.). İstanbul: Hayalperest. 